Masyarakat Madani

- Jurnal Kajian Islam dan Pengembangan Masyarakat

P-ISSN: 2338-607X I E-ISSN: 2656-7741

\title{
COVID-19 DAN PELOSOK DESA TUGU SEMPURNA
}

\author{
Yori Imtaqtar, Dwi Cahya Pranata, Slamet Muliono Redjosari
}

\author{
Sekolah Tinggi Agama Islam Ali Bin Abi Thalib Surabaya \\ Email: dwicahayapranata@gmail.com
}

\begin{abstract}
Artikel ini bertujuan menunjukan bahwa masih meluasnya kasus terpapar COVID 19. Hal ini dibuktikan adanya fakta yang terjadi didesa Tugu sempurna Kecamatan Muara kelingi Kabupaten Musi Rawas SUMSEL. Desa terpencil jauh dari perkotaan, menunjukan pada awal bulan April 2021 pihak dinas kesehatan menyatakan bahwa adanya satu anggota keluarga terpapar virus covid.Telah di telusuri jumlah yang terpapar virus ini telah meluas di Desa Tugu Sempurna hingga berstatus zona merah. Metode untuk menggali data yang di lakukan adalah dengan wawancara tokoh desa dan masyarakat untuk mendapatkan data yang aktual. Temuan riset menunjukan anggapan masyarkat yang salah dengan adanya covid 19, mereka menganggap penyakit ini hanya menimpa bagi mereka yang tinggal di perkotaan akan tetapi anggapan tersebut berbalik dengan adanya fakta desa tugu sempurna terkena wabah tersebut dan masyarakat mempunyai dua pandangan terhadap covid 19 yang pertama menganggap covid 19 sebagai konspirasi dengan alasan adanya pasien covid 19 di desa tugu sempurna yang hari-hari nya sebagai petani dan masyarakat menuduh ini adalah kejadian bohong, dan pendapat yang kedua beranggapan bahwa covid 19 benar adanya, karena salah seorang pasien covid 19 yang sembuh menceritakan sakit yang dia rasakan akibat covid 19.
\end{abstract}

Kata kunci: Covid:19, Desa, Pelosok, perkotaan, Musi rawas, Muara kelinggi

\begin{abstract}
This article shows that there are still widespread cases of exposure to COVID 19. This is proven by the facts that occurred in the village of Tugu Perfect, Muara Kelingi District, Musi Rawas Regency, South Sumatra. Our village is a remote village or far from urban areas, indicating that the community is unlikely to be exposed to covid 19, but in early April 2021 the health department stated that one family member was exposed to the covid virus after traveling from the capital city of Palembang. And this case is still being handled by the district health office. It has been traced that the number of people exposed to this virus has expanded in Tugu Sempurna Village to the status of a red zone. The method for digging up data is by interviewing village and community leaders to get actual data. Research findings show that the community's assumption is wrong with the existence of covid 19, they think this disease only affects those who live in urban areas, but this assumption is reversed by the fact that the Tugu village is completely affected by the outbreak and the community has two views on covid 19. 19 as a conspiracy with the reason that there are covid 19 patients in the village of Tugu perfect whose days as farmers and the community accuse this of being a lie, and the second opinion assumes that covid 19 is true, because one of the recovered covid 19 patients told of a sick illness. he feels the effects of covid 19.
\end{abstract}

Keywords: Covid:19, Desa, Pelosok, perkotaan, Musi rawas, Muara kelinggi 


\section{Pendahuluan.}

Pandemi COVID-19 adalah peristiwa menyebarnya Penyakit koronavirus 2019 (Bahasa Inggris: Coronavirus disease 2019, disingkat COVID-19) di seluruh dunia untuk semua Negara. Penyakit ini disebabkan oleh koronavirus jenis baru yang diberi nama SARS-CoV-2. Wabah COVID-19 pertama kali dideteksi di Kota Wuhan, Hubei, Tiongkok pada tanggal 1 Desember 2019, dan ditetapkan sebagai pandemi oleh Organisasi Kesehatan Dunia (WHO) pada tanggal 11 Maret 2020.Hingga 14 November 2020, lebih dari 53.281.350 orang kasus telah dilaporkan lebih dari 219 negara dan wilayah seluruh dunia, mengakibatkan lebih dari 1.301.021 orang meninggal dunia dan lebih dari 34.394.214 orang sembuh.

Virus SARS-CoV-2 diduga menyebar di antara orang-orang terutama melalui percikan pernapasan (droplet) yang dihasilkan selama batuk. Percikan ini juga dapat dihasilkan dari bersin dan pernapasan normal. Selain itu, virus dapat menyebar akibat menyentuh permukaan benda yang terkontaminasi dan kemudian menyentuh wajah seseorang. Penyakit COVID-19 paling menular saat orang yang menderitanya memiliki gejala, meskipun penyebaran mungkin saja terjadi sebelum gejala muncul. Periode waktu antara paparan virus dan munculnya gejala biasanya sekitar lima hari, tetapi dapat berkisar dari dua hingga empat belas hari. Gejala umum di antaranya demam, batuk, dan sesak napas. Komplikasi dapat berupa pneumonia dan penyakit pernapasan akut berat. Tidak ada vaksin atau pengobatan antivirus khusus untuk penyakit ini. Pengobatan primer yang diberikan berupa terapi simtomatik dan suportif. Langkah-langkah pencegahan yang direkomendasikan di antaranya mencuci tangan, menutup mulut saat batuk, menjaga jarak dari orang lain, serta pemantauan dan isolasi diri untuk orang yang mencurigai bahwa mereka terinfeksi.

Upaya untuk mencegah penyebaran virus corona termasuk pembatasan perjalanan, karantina, pemberlakuan jam malam, penundaan dan pembatalan acara, serta penutupan fasilitas. Upaya ini termasuk karantina Hubei, karantina nasional di Italia dan di tempat lain di Eropa, serta pemberlakuan jam malam di Tiongkok dan Korea Selatan, berbagai penutupan perbatasan negara atau pembatasan penumpang yang masuk, penapisan di bandara dan stasiun kereta, serta informasi perjalanan mengenai daerah dengan transmisi lokal. Sekolah dan universitas telah ditutup baik secara nasional atau lokal di lebih dari 124 negara dan memengaruhi lebih dari 1,2 miliar siswa Pandemi ini 
telah menyebabkan gangguan sosioekonomi global, penundaan atau pembatalan acara olahraga dan budaya, dan kekhawatiran luas tentang kekurangan persediaan barang yang mendorong pembelian panik. Misinformasi dan teori konspirasi tentang virus telah menyebar secara daring, dan telah terjadi insiden xenophobia dan rasisme terhadap orang Tiongkok dan orang-orang Asia Timur atau Asia Tenggara lainnya. ${ }^{1}$

Pandemi COVID-19 telah hampir delapan bulan lamanya mendera Indonesia khususnya daerah perkotaan besar namun berjalanya waktu penyakit ini mulai merambat ke plosok desa dan hal yang paling tidak terduga adalah masuk kedaerah pemukiman pelosok desa yang mayoritas penduduknya masih sederhana dan pekerjaanya pergi ke ladang. Tentu masalah ini berdampak bagi mereka yang tingal di perdesaan mengingat sarana dan prasarana kesehatan masih belum memadahi seperi rumah sakit. Selain memengaruhi kesehatan masyarakat, wabah penyakit yang ditularkan oleh virus ini juga telah melemahkan perekonomian. Tidak hanya berdampak terhadap warga di kota-kota besar, tetapi pandemi juga mewabah hingga ke pelosok desa. Dan dengan cepat, krisis kesehatan dan ekonomi melingkupi hampir seluruh pelosok negeri.

Dengan segenap jiwa dan usaha, pemerintah beserta seluruh komponen bangsa bahu membahu melakukan upaya penanggulangan untuk mengendalikan laju penyebaran.

Awalnya dampak pandemi virus corona jenis baru (COVID-19) riuh di perkotaan, khususnya kota besar, namun saat ini sudah memaparkan pengaruhnya hingga masyarakat desa-desa. Kecepatan persebarannya bukan sebatas virus yang mengganggu kesehatan manusia hingga mengakibatkan jatuh korban jiwa, tetapi juga segala macam informasi yang berseliweran terkait dengannya, terutama di media sosial yang nyaris tanpa bisa dikendalikan.Kabar pandemi virus yang membuat cemas dan upaya mengangkat moral serta semangat publik menghadapi dengan tegar sebaran COVID-19 melalui media sosial sampai juga ke masyarakat desa dan bergulir di kalangan mereka. Sebut saja contohnya, tentang pembuatan portal penutup jalan masuk desa tugu sempurna yang melimpah terjadi di mana-mana dengan pemahaman untuk pencegahan penularan virus.

\footnotetext{
${ }^{1}$ https://id.wikipedia.org/wiki/Pandemi_COVID-19
} 


\section{Metode Penelitian.}

\section{Jenis dan Pendekatan Penelitian}

Jenis dari penelitian ini ialah penelitian deskriptif dengan pendekatan kualitatif, menurut Noor penelitian deskriptif adalah penulisan yang berusaha mendeskripsikan suatu gejala, peristiwa, kejadian yang terjadi sekarang. Penelitian deskriptif memusarkan perhatian pada masalah aktual sebagaimana adanya pada saat penelitian berlangsung.

Penelitian ini juga merupakan penelitian pustaka (library research), yaitu riset yang dilakukan dengan jalan membaca literatur, berupa buku-buku/majalah, jurnal dan sumber data lainnya di dalam perpustakaan. Jadi pengumpulan data dilakukan di perpustakaan atau di tempat lainnya yang tersimpan buku-buku serta sumber-sumber data lainnya. Penelitian ini termasuk dalam penelitian kualitatif, yaitu penelitian menggunakan pendekatan naturalistik untuk mencari dan menemukan pengertian-pengertian atau pemahaman tentang fenomena dalam suatu latar yang khusus.

\section{Teknik Pengumpulan Data}

Untuk memperoleh data dan informasi yang dilakukan dalam penelitian ini maka pengumpulan data melalui:

a. Wawancara

Wawancara adalah pecakapan dengan maksud tertentu, percakapan yang dilakukan oleh dua pihak yaitu pewawancara(interview) yang mengajukan pertanyaan dan terwawancara.

\section{Teknik Analisis Data}

Analisis data merupakan proses mencari dan menyususn secara sistematis data yang diperoleh dari hasil wawancara, catatan lapangan dan bahn-bahan lain, sehingga mudah dipahami dan temuannya dapat di informasikan kepada orang lain, tiga tahapan yang harus dikerjakan dalam menganalisis data penelitian kualitatif yaitu:

a. Reduksi

Reduksi dalam penelitian ini dilakukan dengan merangkum data, memilih hal-hal pokok, disusun sistematis sehingga dapat memberikan gambaran yang lebih jelas tentang hasil pengamatan dan mempermudah peneliti dalam mencari kembali data yang didiproleh bila diperlukan. 
b. Penarikan Kesimpulan

Untuk penarikan kesimpilan peneliti menyusun pola dari data yang terkumpul untuk dijadikan satu agar mudah dipahami

\section{Hasil dan Pembahasan}

\section{Sejarah Covid-19}

Setahun sudah pandemi Covid-19 yang muncul di China, mewabah di seluruh dunia. Setelah menyelesaikan misi penyelidikan asal mula virus corona, tim ahli dari Organisasi Kesehatan Dunia (WHO) akhirnya memberi penjelasan terkait hal ini. Dilansir dari Reuters, Kamis (11/2/2021), tim ahli yang ditunjuk oleh WHO telah menyelesaikan 28 hari misi penyelidikan asal mula virus corona di China, dan telah memperoleh sejumlah petunjuk. Pakar penyakit hewan terkemuka WHO, Peter Ben Embarek mengatakan bahwa ada empat skenario utama tentang bagaimana virus SARS-CoV-2, penyebab Covid-19 ini menyebar ke manusia.

a. Kontak langsung dengan kelelawar Dari hasil penyelidikan, tim mengatakan skenario pertama asal mula virus corona, yakni satu orang terpapar SARS-CoV-2 melalui kontak langsung dengan spesies inang. Spesies inang ini adalah kelelawar tapal kuda, yang mana virus bisa saja beredar pada manusia untuk sementara waktu, sebelum mewabah di antara padatnya penduduk Wuhan.

b. Menular dari spesies perantara Skenario kedua asal mula virus corona yang dianggap paling mungkin terjadi, yakni melibatkan penularan Covid-19 ke manusia melalui spesies perantara yang belum diketahui. Liang Wannian, seorang ahli di Komisi Kesehatan Nasional China mengatakan trenggiling adalah kandidat potensial yang menjadi perantara penularan virus corona.

c. Penularan lewat makanan beku Kemungkinan ketiga, Covid-19 bisa saja berasal dari skenario pertama dan kedua, yang kemudian ditularkan melalui produk makanan beku. Pakar China telah mengaitkan kelompok Covid-19 dengan makanan beku impor dan telah meningkatkan kemungkinan atas hal itu sebagai penyebab munculnya wabah virus corona di Wuhan.

d. Kebocoran virus dari laboratorium Isu kebocoran virus SARS-CoV-2 dari Institut Virologi Wuhan, menjadi kemungkinan yang bisa saja terjadi. Sebab, diketahui bahwa institusi ini telah mempelajari virus corona di penangkaran. Kendati demikian, 
Ben Embarek mengesampingkan kemungkinan itu dan mengatakan tidak akan menjadi subjek penelitian lebih lanjut. "Kecelakaan terjadi, tetapi sangat tidak mungkin dalam kasus ini," kata dia.

Saat ini, masyarakat di seluruh dunia telah terjangkit penyakit coronavirus 2019 (COVID-19), yang merupakan pandemi kelima setelah pandemi flu 1918. Dalam hitungan bulan, wabah COVID-19 telah mengakibatkan krisis di berbagai negara di dunia. Ketahui lebih lanjut tentang sejarah Coronavirus mulai melanda dunia, dibawah ini.

Sejarah Coronavirus bermula pada laporan pertama wabah COVID-19 yang berasal dari sekelompok kasus pneumonia manusia di Kota Wuhan, China, sejak akhir Desember 2019. Tanggal paling awal timbulnya kasus adalah 1 Desember 2019. Gejala dari pasien meliputi demam, malaise, batuk kering, dan dispnea yang didiagnosis sebagai gejala infeksi virus pneumonia. Awalnya, penyakit itu disebut pneumonia Wuhan oleh pers karena gejala yang serupa pneumonia. Hasil sekuensing genom menunjukkan bahwa agen penyebabnya adalah coronavirus baru. Organisasi Kesehatan Dunia (WHO) untuk sementara menamai virus baru 2019 novel coronavirus (2019-nCoV) pada 12 Januari 2020 dan kemudian secara resmi mengubahnya menjadi penyakit coronavirus 2019 (COVID-19) pada 12 Februari 2020.

Penyakit COVID-19 yang disebabkan oleh virus SARS-CoV-2 atau yang dikenal juga dengan coronavirus masih satu keluarga dengan coronavirus penyebab wabah Severe Acute Respiratory Syndrome (SARS) dan Middle East Respiratory Syndrome (MERS). Ketiga wabah ini memiliki kecepatan infeksi yang berbeda dalam menjangkiti para korban. Di antara ketiganya, COVID-19 adalah yang tercepat dalam mengakibatkan infeksi antar manusia.

Lebih lanjut para ahli mengungkapkan meskipun tidak mungkin ada wabah skala besar di Wuhan atau tempat lain di China sebelum Desember 2019, namun mereka tidak menutup kemungkinan bahwa wabah itu menyebar di wilayah lain. ${ }^{2}$

\section{Sebab Masyarakat Desa Tugu sempurna Tertular Covid-19}

Desa tugu sempurna adalah desa yang jauh dari perkotaan, jarak tempuh desa ke kota kecil adalah 4 jam lamanya dengan sepeda motor dan melewati jalan yang belum

${ }^{2}$ https://www.kompas.com/sains/read/2021/02/11/070300223/4-skenario-asal-mula-virus-coronadi-wuhan-menurut-who?page=all 
memadahi seperti bebatuan dan tanah. Desa tugu sempurna terkenal dengan hasil perkebunan karet dan sawit yang kualitasnya bagus di pasaran sehingga mayoritas penduduk desa berprofesikan sebagai petani karet dan sawit meskipun ada sebagaian dari mereka yang berprofesikan sebagai guru dan pegawai kantor desa setempat serta pengusaha sarang walet. Warga desa tugu sempurna mayoritas islam dan ada sebagian yang hindu. Meskipun dengan perbedaan yang ada mereka tetap saling menjaga ketenagan desa dan terlebih waktu pandemi saling menjaga agar tidak meluasnya virus covid di setiap individu.

Sebab awal Covid-19 menulari beberapa warga desa tugu sempurna tidak lain karena mereka terlalai jika virus ini hanya ada di perkotaan, namun salah seorang dari merka berpergian ke kota hingga pulang ke desa telah tertular virus corona dan dengan watak yang kurang baik dari salah seorang yang terpapar virus ia engan untuk melakukan isolasi dan pada akhirnya virus pun menular ke seluruh keluarga nya dan hingga ke berbagai kepala keluarga yang sebelumnya berinteraksi dengan pasien. ${ }^{3}$

\section{Desa Tugu sempurna Tanggap Covid 19}

Sesuai prosedur pencegahan penyebaran penyakit Covid 19 danmelalui dukungan dari seluruh warga desa dan relawan Desa Lawan COVID-19 yang telah terbentuk sejauh ini telah mengupayakan banyak langkah untuk mencegah dan menangani COVID-19 di desa, antara lain dengan memberikan edukasi kepada masyarakat tentang COVID-19, mendata penduduk yang rentan sakit, menyiapkan ruang isolasi COVID-19 di desa, menyemprotkan disinfektan dan menyediakan tempat cuci tangan dengan sabun dan air mengalir di tempat-tempat umum, dan juga menyediakan alat kesehatan untuk deteksi dini, perlindungan dan pencegahan penyebaran wabah yang dikoordinasikan dengan puskesmas. ${ }^{4}$ Warga desa-desa juga didorong membentuk satuan tugas dengan relawannya dalam pencegahan penyebaran virus, sedangkan Program Dana Desa harus dirancang ulang pengelolaaannya untuk mendukung penanganan pandemi.Tidak hanya itu, mereka juga menyediakan alat deteksi dini nonmedis berupa formulir sebagai pedoman wawancara yang diisi oleh warga, menyediakan informasi nomor telepon rumah sakit rujukan COVID-19, nomor telepon ambulans dan lain-lain, mendirikan pos jaga gerbang desa, memastikan tidak ada kerumunan hingga penyiapan dan penanganan logistik untuk

\footnotetext{
${ }^{3}$ Eni Suryaningsih Wawancara Rabu 14 April 2021

${ }^{4}$ Ibid
} 
kepentingan warga desa yang menjalani isolasi. Dengan upaya pencegahan dan penanganan tersebut, kegiatan Desa Tanggap COVID-19 tercatat telah sampai ke tingkat nasional dan dengan kewajiban bagi pendatang untuk melakukan isolasi mandiri di ruang isolasi desa.

\section{Proses Penjegahan Penyebaran Covid-19 Desa Tugu sempurna}

Proses penyebaran COVID 19 di Indonesia begitu cepat, maka dari itu kami desa Tugu sempurna mengadakan pencegahan ketat terkait dengan penyebaran corona di desa dengan menjaga dari

1. Kerumunan di tempat umum

2. Menjaga kebersihan tempat ibadah dengan berbagai protokol kesehatan.

3. Mengadakan pemeriksaan tamu luar desa di posko pemeriksaan.

4.Melaksanakan ibadah di rumah untuk sementara waktu.

5. Tidak melaksanakan walimahan atau acara yang mengundang kerumunan.

6. Menyediakan tim untuk merazia warga yang tidak memakai masker.

7. Penyemprotan tempat ibadah rutin.

Di samping dari tahap-tahap terebut perangkat desa setempat meminta warga untuk saling sadar akan waspadaya penyebaran virus covid-19. ${ }^{5}$

\section{Perbedaan kondisi kasus Covid 19 di perkotaan dan perdesaan}

Pertama, jumlah penduduk, yang mana di perkotaan jumlah penduduknya lebih tinggi daripada wilayah kabupaten dan, 55 persen penduduk Indonesia berada di kota.

"Kedua, kepadatan penduduk jika dihitung dengan luas per kilometer persegi. Dengan jumlah penduduk banyak dan area tidak terlalu besar sehingga menyebabkan kepadatan penduduk jauh lebih tinggi di perkotaan.

Ketiga, di perkotaan lebih banyak titik-titik yang memungkinkan masyarakat berkumpul dalam jumlah yang banyak, contohnya, pusat perbelanjaan, bioskop, pusat kebugaran dan sebagainya.

Keempat, Secara kesehatan terutama menyangkut daya tahan tubuh dari serangan virus, mungkin kalangan warga desa yang umumnya petani, jauh lebih baik ketimbang mereka yang tinggal di perkotaan apalagi tidak rajin berolahraga. Petani setiap hari bergulat dengan alam dan lahan pertanian membuat daya tahan tubuh relatif lebih fit.

\footnotetext{
${ }^{5}$ Sukoyo, wawancara $22-$ Mei-2021
} 


\section{Bahaya Covid-19}

Corona virus desease 19 yang disingkat dengan covid 19 adalah keluarga besar virus yang menyebabkan penyakit pada manusia dan hewan. Virus ini ditemukan pada 31 Desember 2019 di Wuhan, China. WHO (Wordl Health Organization) memberi nama covid-19 dengan nama Severe Acute Respiratory Syndrome Coronavirus -2 (SARS-CoV2). Selanjutnya, WHO menyebut penyakit yang ditimbulkan oleh virus ini dengan nama Corona Virus Desease 2019 (COVID-19). Covid-19 merupakan virus RNA strain tunggal positif. Virus ini disebut dengan virus zoonotik, yaitu virus yang ditransmisikan dari hewan kepada manusia bersifat sensitif terhadap panas. Virus ini dapat diinaktifkan oleh disinfektan. Virus ini berbahaya, karena transmisi atau penyebarannya yang cepat dan lebih mudah dibandingkan wabah SARS yang pernah melanda dunia pada tahun 2003. Virus ini menyerang saluran pernapasan manusia. Virus ini dapat menyebar melalui tetesan kecil (droplet) dari hidung atau mulut penderita pada saat batuk atau bersin.

Adapun proses transmisinya dapat terjadi dengan tiga metode yaitu: pertama, droplet penderita pada saat batuk atau bersin jatuh pada benda di sekitarnya. Kemudian, ada orang lain menyentuh benda yang sudah terkontaminasi dengan droplet tersebut, kemudian orang tersebut menyentuh mata, hidung, atau mulut (segitiga wajah) sebelum mencuci tangan, maka orang tersebut dapat terinfeksi Covid-19. Kedua, seseorang tanpa sengaja menghirup droplet dari penderita covid 19. Ketiga, kontak pribadi seperti berjabat tangan.

Adapun gejala awal dari penyakit yayng disebabkan covid 19 adalah demam (suhu tubuh di atas 38 derajat celcius, batuk kering, pilek, gangguan pernapasan, sakit tenggorokan, letih, dan lesu. Ada beberapa gejala lain yang juga bisa muncul pada infeksi virus covid 19, akan tetapi jarang terjadi, yaitu: diare, sakit kepala,konjungtivitis, hilangnya kemampuan mengecap rasa atau mencium bau, ruam di kulit. Gejala-gejala COVID-19 ini umumnya muncul dalam waktu 2 hari sampai 2 minggu setelah penderita terpapar virus Corona. Menurut Organisasi Kesehatan Dunia (WHO) 6 persen penderita mengalami gejala kritis seperti gangguan pada paru, septic shock hingga risiko kematian. Sebanya persen mengalami gejala berat seperti kesulitan bernapas dan sesak napas. Delapan puluh persen lainnya memiliki gejala ringan seperti demam, batuk dan beberapa memiliki pneumonia. 
Meski penyakit covid 19 tidak mematikan, akan tetapi penyakit ini dinyatakan sangat berbahaya untuk kesehatan. Sebab, pertama, penyakit ini merupakan penyakit infeksi. Kedua, virusnya begitu agresif. Ketiga, tingkat penularan yang tinggi. Keempat, penularannya bisa melalui interaksi antar personal. Kelima, bagi orang yang memiliki riwayat penyakit tertentu lebih rentan terkena virus corona dan mengalami komplikasi parah ketika positif COVID-19.29 Keenam, dapat merusak paru-paru, bahkan dapat menyebabkan kerusakan paru permanen bagi penderita yang memiliki kemampuan regenerasi paru yang rendah seperti pada lansia, pasien yang memiliki penyakit penyerta, dan perokok. Adapun kelompok yang sangat rentan dan berpotensi memiliki gejala berat hingga kritis jika terinfeksi covid-19 adalah lansia.

\section{Kesimpulan.}

Seiring berkembangnya wabah Covid 19 semakin banyak pula yang terinnfeksi oleh wabah ini, baik tua, muda, maupun anak-anak semuanya tak luput dari ancaman Wabah ini, meskipun demikian masih ada saja masyrakat yang tidak mempercayai adanya covid, Sebagian mereka menganggap virus ini hanyalah konspirasi terlepas dari benar tidaknya berita tersebut akan tetapi apa yang di anjurkan oleh medis merupakan hal yang baik, seperti menggunakan masker dan lain sebagainya adalah bukan tanpa alasan, dan diantara sebab tidak percayanya masyarakat dengan adanya covid adalah karena masalah ekonomi yang tidak mendukung, biasanya hal ini terjadi pada masyarakat menengah kebawah, dan golongan ini biasanya ada di luar perkotaan seperti desa dan daerah daerah pelosok, tanpa menafikan mereka yang tinggal di perkotaan, seperti masyarakat yang menengah kebawah adalah mereka yang biasanya memiliki usaha di pasar pasar tradisional, mereka beranggapan bahwa jika "segala sesuatu dicopad copid kan kapan dapat uangnya" maka dari itu kebanyakan mereka yang melanggar protocol Kesehatan itu adalah orang yang memiliki pas pas-an, semakin mereka kaya semakin takut pula mereka dengan covid, sebaliknya semakin mereka miskin mereka pun semakin tidak percaya covid, kebanyakan mereka yang tidak peduli covid adalah mereka yang memiliki ekonomi menegah kebawah, khususnya mereka yang berada di pedesaan, tak dapat dipunkiri mereka pun kebanyakan tidak peduli covid dan acuh terhadapa protocol Kesehatan. karena bagi mereka apapun yang terjadi tetap lakukan aktifitas seperti biasa, hal ini lah yang menyebabkan covid pun bisa memasuki daerah pedesaan. 


\section{Daftar Pustaka}

Kadeni Dan Ninik Srijani, Peran Umkm (Usaha Mikro Kecil Menengah) Dalam Meningkatkan Kesejahtraan Masyarakat, E-Jurnal, Volume 8, Nomor 2 (Januaru 2021)

Lincolin Arsyad, dkk. Strategi pembangunan perdesaan berbasis lokal. Yogyakarta: upp stim ykpn. 2018

Mardikanto, Totok, dan Poerwoko Soebianom. Pemberdayaan masyrakat dalam prefektif kebijakan public. Jakarta: Alfabeta, 2017.

Aziz muslim. Methodologi Pengembangan Masyarakat. Yogyakarta: Bidang Akademik, UIN Sunan kalijaga, 2008..

Sri Sugianti, Peran Usaha Mikro Kecil Dan Menengah Dalam Mensejahtrakana Karyawan Di Pusat Oleh-Oleh Mak Denok Di Desa Serdang Jaya. Universitas Islam Negri Sultan Thaha Saifudin Jambi, Skripsi (2019).

Sugiyono, Metodologi Penelitian Kuantitatif Kualitatif dan R\&D, cet ke-22 (Bandung: Alfabeta,2015)

https://www.kompas.com/sains/read/2021/02/11/070300223/4-skenario-asal-mulavirus-corona-di-wuhan-menurut-who?page=all.

https://id.wikipedia.org/wiki/Pandemi_COVID-19

Wawancara: dr, Eni Suryaningsih Rabu 14 April 2021

Wawancara: Sukoyo, wawancara $22-M e i-2021$ 